\section{UV-B radiation was the Devonian-Carboniferous boundary terrestrial extinction kill mechanism}

\author{
John E. A. Marshall ${ }^{1 *}$, Jon Lakin ${ }^{1}$, Ian Troth ${ }^{1}$, Sarah M. Wallace-Johnson ${ }^{2}$
}

\begin{abstract}
There is an unexplained terrestrial mass extinction at the Devonian-Carboniferous boundary ( 359 million years ago). The discovery in east Greenland of malformed land plant spores demonstrates that the extinction was coincident with elevated UV-B radiation demonstrating ozone layer reduction. Mercury data through the extinction level prove that, unlike other mass extinctions, there were no planetary scale volcanic eruptions. Importantly, the Devonian-Carboniferous boundary terrestrial mass extinction was coincident with a major climatic warming that ended the intense final glacial cycle of the latest Devonian ice age. A mechanism for ozone layer reduction during rapid warming is increased convective transport of $\mathrm{ClO}$. Hence, ozone loss during rapid warming is an inherent Earth system process with the unavoidable conclusion that we should be alert for such an eventuality in the future warming world.
\end{abstract}

\section{INTRODUCTION}

The end-Devonian mass extinction [or Hangenberg Crisis, 359 million years (Ma) ago (1)] is now included $(2,3)$ among the first-order mass extinctions. The extinction was a multiple biotic crisis with an early main phase of marine extinctions associated with black shales and anoxia (2) separated by an estimated 300 thousand years $(\mathrm{ka})$ (1) from a terrestrial mass extinction of fish (4) with coincident extinctions (5) in land plants. Regarding pollen and spores, the terrestrial extinction is clearly expressed as the complete loss of diversity $(6,7)$ across the Devonian-Carboniferous (D-C) boundary with the extinction of at least four major spore groups that had dominated the spore assemblage (7). The immediate post-extinction VI spore assemblage was remarkable for its simplicity (6) with the recovery vegetation dominated by small simple land plants. Hence, the event was a major ecosystem disruption that included the collapse of the structured forest community (8).

Here, we report on a transect (Fig. 1) of terrestrial D-C boundary sections from East Greenland that all include the extinction level. One section is unique in containing abundant plant spores and spore tetrads with malformed sculpture and pigmented walls. These malformations are entirely consistent (9) with exposure to elevated levels of ultraviolet-B (UV-B) that damaged the DNA before the formation of their protective sporopollenin walls. This indicates the temporary loss of the global protective ozone layer.

\section{RESULTS}

In East Greenland, the $\mathrm{D}$-C boundary is a 2- to 4-m-thick interval with two permanent lakes that can be traced (Fig. 1) along a 75-km-long transect from distal and deep to proximal shallow water environments. The thickest, most distal section of these lakes is on Stensiö Bjerg (Fig. 1 and fig. S1). The lower lake includes a 0.5 -m-thick interval of mudstone of very latest Devonian age [Retispora lepidophyta Verrucosisporites nitidus (LN) transitional spore zone (10), here labeled as $\left.\mathrm{LN}^{*}\right]$. Above this zone, there is a 0.8 -m-thick interval through

\footnotetext{
'School of Ocean and Earth Science, University of Southampton, National Oceanography Centre, European Way, Southampton SO14 3ZH, UK. ${ }^{2}$ The Sedgwick Museum of Earth Sciences, Brighton Building, Madingley Rise, Cambridge CB3 OEZ, UK. *Corresponding author. Email: jeam@soton.ac.uk
}

which the total organic carbon content (TOC weight \%; table S1) progressively increases to the quite exceptional maximum of $21 \%$ in the midpoint of the bed. However, a consequence of the high organic matter content is that, as TOC\% increased above 2\% (Fig. 1), amorphous organic matter (AOM) dominates and spore recovery is lost. Spores are only found again in the upper lake, but as the low diversity postextinction VI spore assemblage $(6,7)$ of very earliest Carboniferous age.

The spore assemblage in the 160-m-thick Stensiö Bjerg Formation (figs. S2 to S4) below the lakes is of low diversity (largely Retispora lepidophyta and Diducites spp). As the lower lake started to form, the paleoenvironment became wetter and more humid, and with it, the spore diversity strikingly increased, which defines the $\mathrm{LN}^{*}$ zone. However, as the lake further developed, spore diversity sharply declined with extinctions of major spore groups (figs. S3 and S4) that were formerly diverse, widely distributed, and long ranging through the Mid and Late Devonian. These include R. lepidophyta that had achieved a global distribution in the latest Famennian, all of the diverse group of lycopod spores with bifurcate tips (e.g., Ancyrospora), and Diducites spp, which is the spore of Rhacophyton (11) that formed the understory layer to the Devonian forests.

The data that we have collected from the D-C boundary interval on Celsius Bjerg (Fig. 2, table S2, and fig. S5) enable us to link these spore extinctions to the megafossil record, as tree-sized plant stems are abundant in this more proximal section. These stems represent the downstream accumulation of plant debris from forests present upstream. Our data show that these large stems suddenly and entirely disappear exactly at the D-C boundary and remained absent for the Tournaisian, i.e., the first $7 \mathrm{Ma}$ (12) of the early Carboniferous. This marks the collapse of the main forest canopy and was coincident with the extinction of Diducites. However, many of the plant groups that formed these first forests reappeared later and had survived as scattered remnants (13). On Celsius Bjerg, we can also recognize the sedimentological response to this collapse (fig. S6), as the fluvial sandstones above the boundary were deposited by more active largerscale systems that reflected increased sediment transport in the absence of a structured terrestrial vegetation community.

The missing spore record from the lower lake on Stensiö Bjerg was found at Rebild Bakker (14) (Fig. 1 and table S3). Here, the two boundary lakes occur within fluvial sandstones and immediately above palynologically dated latest Devonian sediments. The 50-cm-thick 


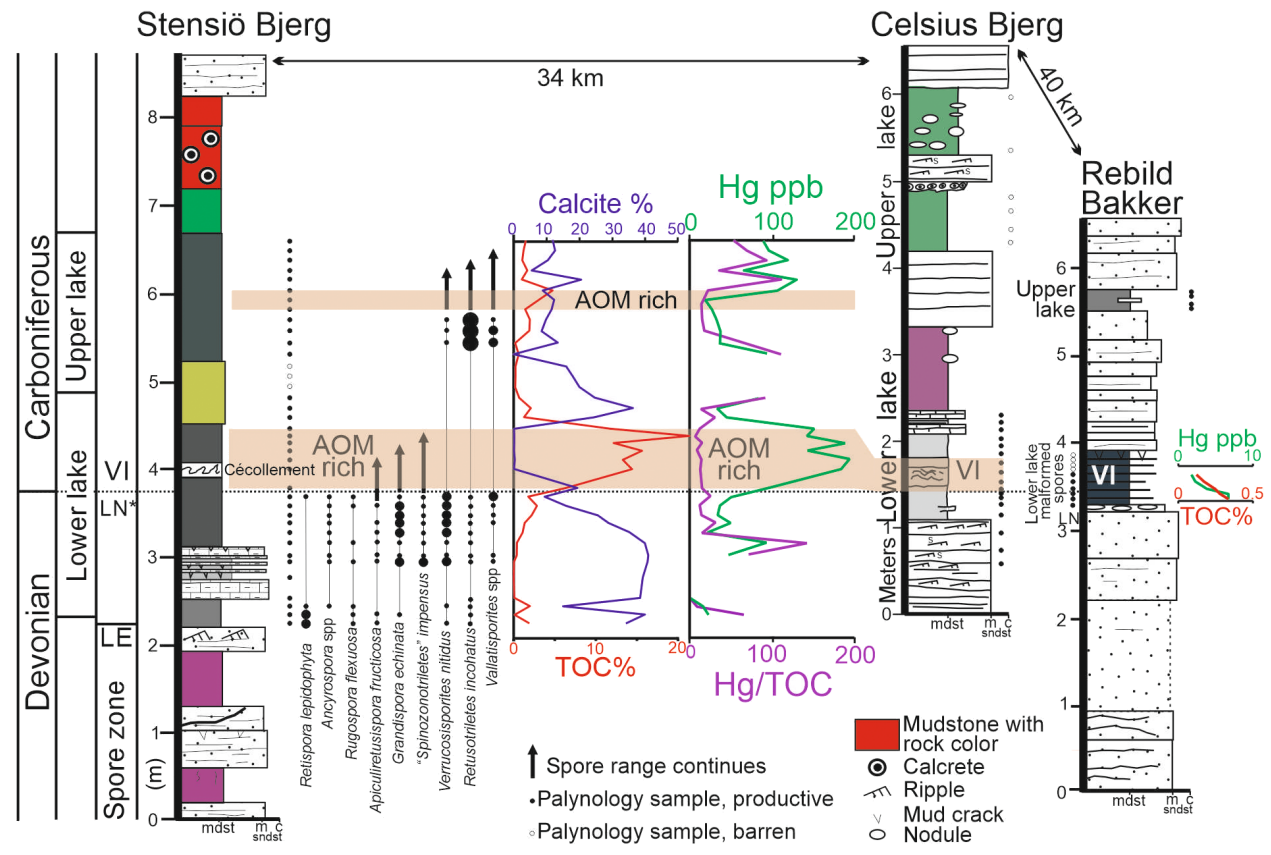

Fig. 1. A deep (left) to shallow water (right) lake transect through the D-C boundary in East Greenland. As the lower lake flooded (Stensiö Bjerg), spore diversity increased (LN* zone) until recovery was lost in the high-TOC AOM-rich interval. The upper lake contains VI spores of earliest Carboniferous in age. The LN* to VI spore zone correlates the lower lake to the more proximal locations on Celsius Bjerg and Rebild Bakker. At Rebild Bakker, the lower lake contains high numbers of malformed and dark-colored VI zone spores of earliest Carboniferous age. The high $\mathrm{Hg}$ content at Stensiö Bjerg is coincident with both a high TOC and AOM content. However, when normalized as Hg/TOC, there is no anomaly characteristic of a large igneous province (LIP) eruption. This level is coincident with the malformed spores at Rebild Bakker, where, in the absence of AOM, Hg content is low again, indicating that there was no LIP. Analytical data are presented in table S1. mdst, mudstone; sndst, sandstone; m, medium sandstone; c, coarse sandstone.

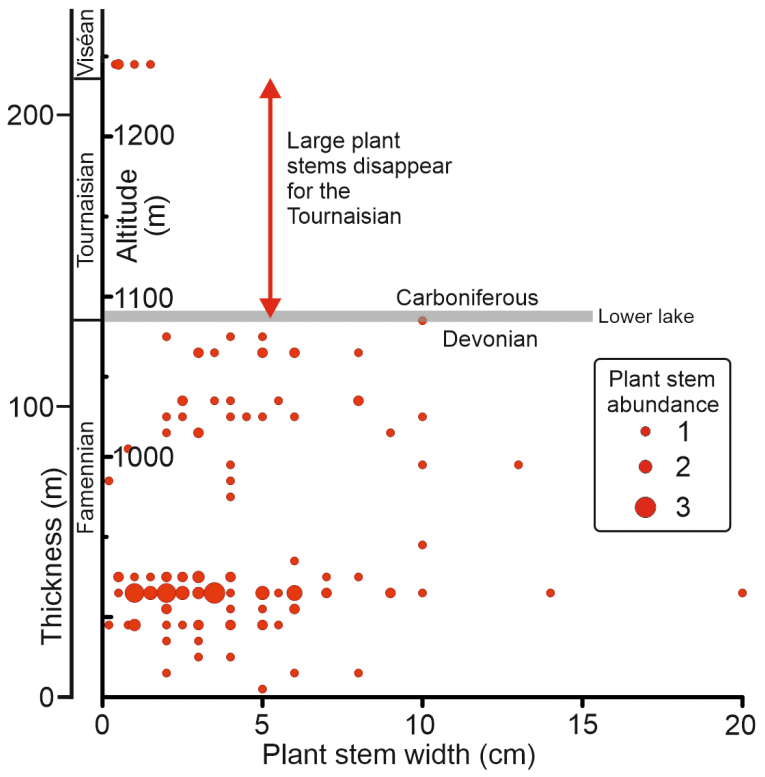

Fig. 2. Abundance, distribution, and width of the stems of plant fossils through the D-C boundary on Celsius Bjerg. The maximum diameter and number of the stems are plotted against the altitude and section thickness. Large plants completely and abruptly disappear at the D-C boundary in the lower lake and remain absent for the $7 \mathrm{Ma}$ of the Tournaisian. The plant data are in table S2.

lower lake contains no AOM, and five samples from its lower part contain well-preserved, low thermal maturity spores. All the spores that became extinct at the D-C boundary are absent apart from a single specimen of $R$. lepidophyta at $9 \mathrm{~cm}$ above the base. The top of the Devonian is picked at this and the corresponding level at Stensiö Bjerg. This shows that the missing 0.8-m AOM-rich interval from Stensiö Bjerg was earliest Carboniferous in age.

The spores from this marginal lake environment are morphologically more diverse. They include Grandispora cornuta that has long spines that demonstrate a number of unique and highly atypical malformations (Fig. 3 and figs. S7 and S8) and that reveal the unusual conditions that drove the terrestrial extinctions. G. cornuta is well known in other D-C boundary sections $(6,15)$ and normal specimens (Fig. 3, D and E) had two wall layers, with the outer wall covered with near-identical long spines (15 to 30 in number) that are regularly spaced, similar in length, and taper evenly to pointed tips. G. cornuta also have regular circular spots between each inter-ray of the trilete mark, an unusual feature for spores from the $\mathrm{D}$-C boundary interval, which enables it to be uniquely identified even as fragmentary malformed specimens. At Rebild Bakker, malformed specimens of G. cornuta are the majority (Fig. 3, F to W) and increase upward in relative abundance through the lower lake from 71 to 95\% (Fig. 3A). The commonest malformation is that the spines become both irregularly spaced (e.g., Fig. 3, F, H, and J) and reduced in number, sometimes to as few as five. These spines show a variety of malformed tips that are not evenly pointed, but instead variously became blunt, irregular-shaped crooks, sinuously elongate, or fused together. In other specimens, the sculpture is coalesced and entwined as residual stumps (Fig. 3, K, N, and P) or elongated with crook ends (Fig. 3, L and S). On a few specimens, the sculpture was deposited as an irregular mass (Fig. 3O). On rare specimens, the inner wall never formed (Fig. 3L), whereas others (Fig. 3Q) never developed the outer wall. The latter can occur in tetrads (Fig. 3V), so they are not isolated inner walls from broken spores. Tetrads representing 

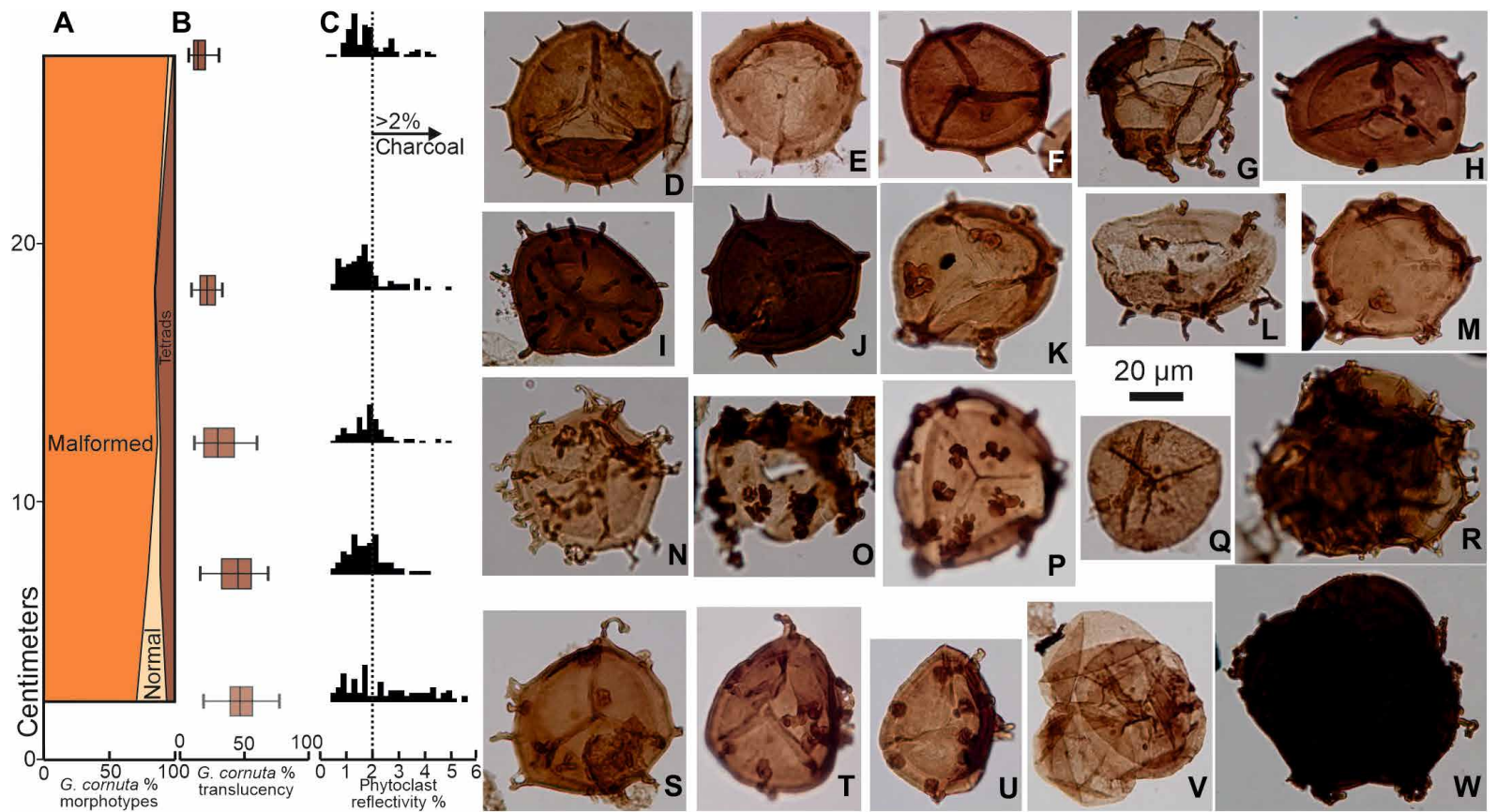

Fig. 3. Normal and malformed G. cornuta from the lower lake, Rebild Bakker. (A) Upward increasing percent of malformed and tetrads. (B) Average translucency of G. cornuta showing increased pigmentation as malformations increase. (C) Dispersed phytoclast reflectivity showing a high charcoal content (>2\%) through the boundary interval and hence no reduction in ozone from lower atmospheric $\mathrm{PO}_{2}$. (D and $\left.\mathbf{E}\right)$ Normal specimens of $G$. cornuta. (F), (H), and $(\mathbf{J})$ show reduced numbers of irregularly distributed spines and increased brown pigmentation. (G) has irregularly developed sinuose processes. (I) has hooked tips. (K) to $(\mathbf{M}),(\mathbf{P})$, and (U) have processes that are reduced in number and irregularly fused. (N), (S), and (T) are irregularly distributed, fused in groups, and highly irregular. (O) has irregular sporopollenin masses adhering to inner body. (V) is a tetrad of inner bodies, whereas (Q) is an isolated inner body. (R) and (W) are tetrads, with irregular sculpture, with (W) being pigmented to a dark brown color. Sample and slide numbers plus England Finder coordinates are in table S4. Translucency data are in table S3, and phytoclast reflectivity data are in table S5.

unseparated meiotic spores are common (15\% maximum; Fig. 3, A, R, and $\mathrm{W}$ ) and show the full range of spine modifications, as shown on the isolated single spores.

Many of the specimens, both tetrads and isolated spores, are brown in color (Fig. 3, $\mathrm{H}$ to J and W). This contrasts with the low thermal maturity level demonstrated by the yellow-orange spore colors (Fig. 3, A to $\mathrm{C}$ and $\mathrm{N}$ to $\mathrm{P}$ ) from the beds immediately above and below, a value confirmed by a vitrinite reflectivity of $0.7 \%$ (table S3), equivalent to a maximum burial temperature of $107^{\circ} \mathrm{C}$. These color variations in the lower lake were measured on 50 single specimens of G. cornuta from each sample (Fig. 3B and table S3) and show that the average translucency declined progressively from $50 \%$ at the base of the bed to $10 \%$ in the highest sample and in parallel with the increase in proportion of malformed specimens.

These distinctive specimens of G. cornuta focus attention on other spores within the lower lake that, on examination, also display pervasive malformations. Figure 4 shows the spore Verrucosisporites nitidus, another well-known species (16) that crosses the D-C boundary. Both below (Fig. 4, A to C) and above (Fig. 4, $\mathrm{N}$ to $\mathrm{P}$ ) the boundary, these spores are pale in color and with a well-formed sculpture of verrucae. Within the lower lake, $V$. nitidus shows a continuous range of morphologies from typical to aberrant forms. However, most specimens that have a well-formed sculpture are brown in color. A minority are pale, smaller in diameter, and with a sculpture that did not fully form, the elements being irregularly spaced and uneven in size. It would appear that spores that developed this pigmentation also acquired a degree of protection during spore wall development. It is more difficult to track malformation in the remainder of the lower lake palynological assemblage, as most of the species in this simple spore assemblage lack spines and have smooth walls. Many of these, in East Greenland and elsewhere, are also dark brown in color and remain so through the entirety of the VI spore zone. However, obvious malformed spores are absent from the upper lake in all three sections that were studied, showing that the cause of the damage has ceased.

Malformations in spore and pollen walls are well documented in both living $(9,17)$ and fossil pollen $(9,18)$ and result from damage to the DNA [typically fusion of opposing base pairs (19)] that occurs before deposition of the protective sporopollenin wall layer. The pollen are then unable to replicate the intricate and regular pattern of the wall sculpture. Such DNA damage can be produced experimentally by exposure to UV-B radiation (17) and atmospheric pollutants (20). Examples from fossil material include the Permo-Triassic $(9,18,21,22)$ and Triassic-Jurassic (23) mass extinctions, where both conifer pollen and spore tetrads show malformation that have generally been interpreted as the direct effect of volcanic gases from large igneous province (LIP) eruptions. However, following experiments with living conifers (9), this has been reinterpreted for the Permo-Triassic mass extinction as the initial destruction of the ozone layer by volcanic gases with the increased UV-B flux and then damaging the pollen and spore DNA. In contrast, that from the Triassic-Jurassic has been attributed (24) to the genotoxic effects of mercury $(\mathrm{Hg})$ generated during LIP eruptions.

Dark-colored spores are also reported from the Permo-Triassic (22) and Triassic-Jurassic (23) mass extinction levels. Although cause and effect remain unproven, spore and pollen walls are naturally 

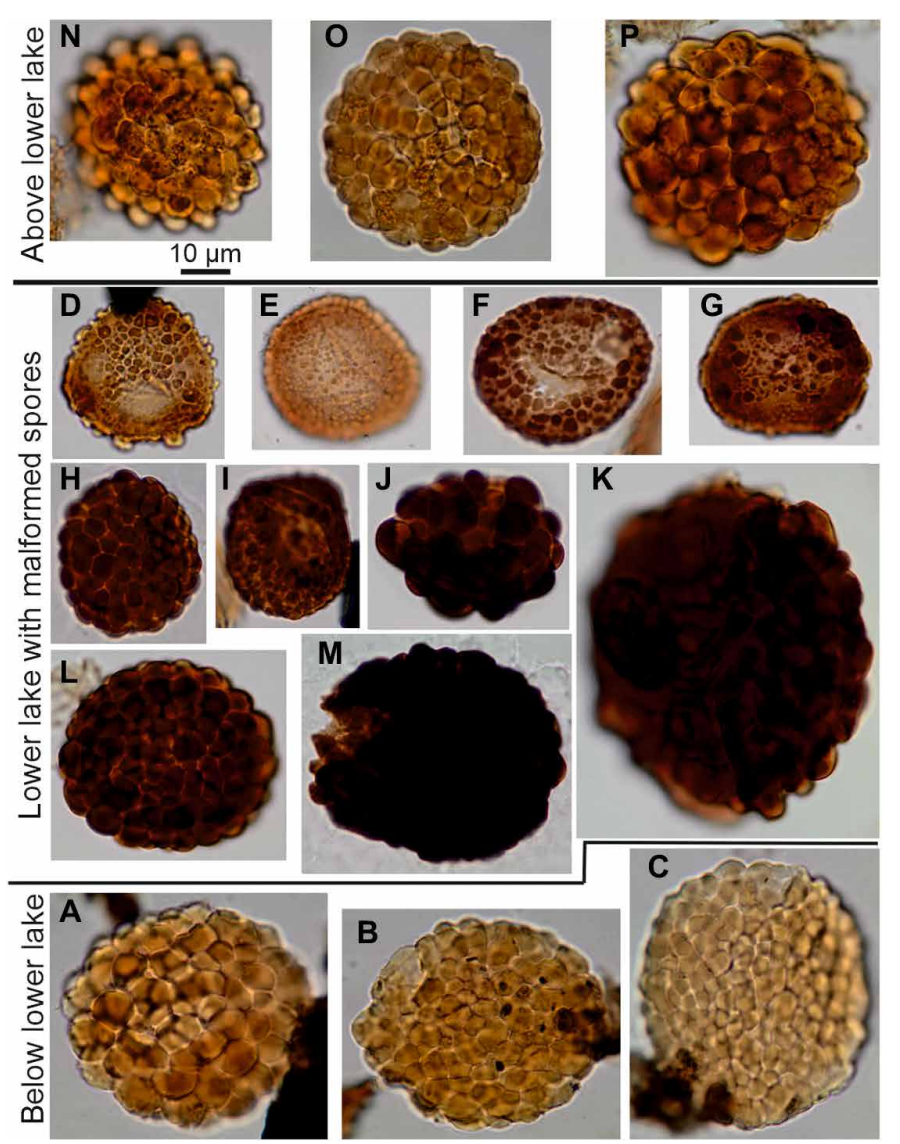

Fig. 4. V. nitidus spores from below, in, and above the $D-C$ boundary showing UV-B malformations. (A) to (C) are from below the boundary (Stensiö Bjerg) and have the characteristic packed verrucae sculpture of $V$. nitidus. (D) to (K) are from the lower lake (Rebild Bakker), with (H) to (M) more strongly pigmented and more regular sculpture with a wider range of diameter than normal. (D) to (G) are paler in color and smaller in size and have irregularly developed sculpture. $(\mathbf{N})$ to $(\mathbf{P})$ are normal specimens of $V$. nitidus from the upper lake bed (Rebild Bakker). Sample and slide numbers plus England Finder coordinates are in table S4.

pigmented yellow to provide protection (25) against UV-B so any additional opacity increases this protection.

Malformed spores are known (26) from other D-C boundary sections. An important record is from Poland (26) immediately below the D-C boundary (LN spore zone) that includes many malformed specimens of Vallatisporites together with spore tetrads. However, both malformed spores and tetrads are rare in Poland, with only a single sample containing tetrads above $3 \%$ that is the background mutation level (18) within normal population of gymnosperm pollen. In addition, there (26) was only a single available VI spore zone sample (and that contained only poorly preserved spores) that is coeval with the malformed spores from Rebild Bakker. These malformations from Poland were attributed (26) to the effects of volcanic eruptions. Another record is from Belgium (27), where malformed spores of equivalent age to the LN spore zone were attributed to cooling/aridity. Again, the Belgian section in common with Poland had no spore recovery in the earliest Carboniferous VI zone that was when the maximum malformation occurred in East Greenland.

Our record of malformed pollen and spores informs us that the kill mechanism acting during the mass extinction was an interval of elevated UV-B related to the loss of the protective ozone layer. The kill mechanism inferred for the Frasnian-Famennian (Late Devonian), end Permian, and Triassic-Jurassic mass extinctions is a collapse of the Earth system linked to known LIPs, which are also evidenced $(28,29)$ by $\mathrm{Hg}$ anomalies. In contrast, compiled records $(26,29,30)$ of igneous activity for the $\mathrm{D}-\mathrm{C}$ boundary show nothing that approached the planetary scale of a LIP eruption.

To test the LIP hypothesis [and as advocated in (31)], we analyzed Hg through the Stensiö Bjerg, Celsius Bjerg, and Rebild Bakker D-C boundary sections. The results (Fig. 1, tables S1 and S3, and fig. S9) show a number of clear peaks from Stensiö Bjerg. However, when the $\mathrm{Hg}$ values are normalized against TOC, the peak coincident with the AOM-rich, high-TOC interval disappears. Hg and TOC analyses (Fig. 1 and fig. S9) from the correlative Rebild Bakker samples (that lack AOM) only reach a maximum of 7 parts per billion (ppb) and $0.3 \%$, respectively. When normalized as $\mathrm{Hg} / \mathrm{TOC}$, the values range from 14 to 26, similar to those from Stensiö Bjerg. Therefore, there is no $\mathrm{Hg}$ anomaly coincident with the malformed spores, i.e., at exactly the extinction level. Hg is well known (32) to be readily absorbed from lake waters by AOM. Hence, a high content simply reflects high AOM absorbing the available $\mathrm{Hg}$. The remaining $\mathrm{Hg} / \mathrm{TOC}$ peaks at Stensiö Bjerg (Fig. 1) are coincident with the shifts between carbonate and organic matter-dominated sediments. $\mathrm{Hg}$ is also known (32) to become more concentrated in lake waters that lack organic matter. This then becomes available in excess to become absorbed onto any subsequent AOM produced. These, the first records of $\mathrm{Hg}$ through a terrestrial $\mathrm{D}-\mathrm{C}$ boundary section, in common with marine records from China (33), the Czech Republic (33), and Vietnam (31), have yet to demonstrate convincing evidence (28) for a LIP.

A second mechanism to explain an ozone collapse would be the widely repeated hypothesis (34) of reduced atmospheric $\mathrm{PO}_{2}$ (partial pressure of oxygen) across the $\mathrm{D}-\mathrm{C}$ boundary. This, if correct, would lead to a reduced level of ozone. However, this hypothesis can be refuted as the boundary bed (Fig. 3C and table S5), and the entire Devonian and Carboniferous section in East Greenland and elsewhere (35) contains abundant highly reflective dispersed charcoal with reflectivities over $2 \%$ and hence of unequivocal wildfire origin. This, in common with a recently updated atmospheric oxygen modeling curve (36), shows that $\mathrm{PO}_{2}$ was in excess of $16.5 \%$ (37).

Regarding the likelihood of DNA damage from local eruptions of volcanic gases, there are no known occurrences of volcanic rocks at this time in east Greenland, the closest in age (38) being some $13 \mathrm{Ma}$ earlier. With regard to airborne pollutants, the evidence (20) from pollen malformation at, for example, modern smelter sites shows that concentrations have to be very high to have any effect. So, this effect can also be discounted as a malformation mechanism because the sedimentary sections (38) through the D-C boundary interval, and throughout the basin, contains no unusual sediments that are indicative of abnormal chemically derived airborne exhalatives.

\section{DISCUSSION}

The key observation to understanding the loss of the D-C boundary ozone layer is that the malformed spores occur exactly coincident with the lower lake. In addition, the proportion of these malformed spores and their degree of darkening systematically increases to the midpoint of the lake bed. The pair of lakes present at the D-C boundary was laterally extensive (38) (at least 50,000 $\mathrm{km}^{2}$ ), with exceptionally high TOC contents, and represents long-lived deep lacustrine 
systems with a stratified water column. The presence of these lakes is in stark contrast to the normal pattern of dryland fluvial and aeolian sedimentary deposition through the $7 \mathrm{~km}$ and $60 \mathrm{Ma}$ of the Devonian to early Carboniferous succession in East Greenland. This prevailing aridity is entirely consistent with its location (39), both in the interior of the Old Red Sandstone Continent (some $1000 \mathrm{~km}$ from the sea) and at $15^{\circ}$ paleosouth in the southern arid zone. Such large lakes can only form when there is sustained seasonal rainfall sufficient to maintain a perennial standing body of fresh water. The mechanisms that bring the required intensity of seasonal rainfall into such an arid zone continental interior are well understood from many Quaternary (40) and deep-time examples $(41,42)$. The process is that high summer temperatures in the continental interior cause a reversal of the normal circulation. This reversal draws in moisture-laden air, which then rises and cools to produces an intense seasonal monsoon. In these models, the lakes were thermal highs and, from their normally arid continental interior locations, represent episodes of exceptional and sustained warming. This places the maximum degree of spore malformation at the midpoint of the lower lake coincident with the thermal maximum. This warming is in contrast to the cooling that a LIP causes during the actual eruption, i.e., when the malformation would occur. LIP-related cooling is the direct result (3) of the dual impact of high levels of both ash and $\mathrm{SO}_{2}$ in the atmosphere and further evidence for the absence of planetary scale volcanism at the D-C boundary.

The coincidence of maximum malformation with the climatic maximum now leads us to look for a mechanism for ozone loss driven by increasing temperature. Combined modern observation and modeling data (43) from the continental United States provide such an ozone removal mechanism with an observed increase in mid-latitude summer temperature, leading to an increase in the convective injection of water vapor into the lower stratosphere. This increased high-altitude water content then passes the threshold (43) for an increased production of catalytically active $\mathrm{ClO}$ with ensuing increased rate of ozone loss.

A positive feedback mechanism could also be at play in the Late Devonian and early Carboniferous, as there were extensive shelf seas with high volumes of carbon burial $(2,44)$ and hence high organic productivity. Methyl halogens are produced naturally by a wide range of organisms (45); hence, any increased organic productivity ultimately increased supply. Progressive ozone loss and increased influx of damaging UV-B would have led to the observed collapse of the Devonian forest environment together with its structured community. The resultant higher rates of runoff would then produce a one-time nutrient flush into the shelf seas and hence increased production of methyl halogens. The process only slowed when temperatures fell from the peak of the lacustrine cycle, allowing the ozone layer to reestablish. A time duration can be estimated from the thickness $(0.8 \mathrm{~m})$ of the exceptionally high TOC interval in the lake deposit at Stensiö Bjerg that represents the most persistent stratification and warmest conditions. It represents about $50 \%$ of the lacustrine cycle, so if driven by precession $(42,46)$, a duration of about 9 ka is likely, although it must be noted that many of the spores had already disappeared earlier in this lake cycle with the malformations being a characteristic of the survivors.

The Stensiö Bjerg sediments in the interval immediately below the two boundary lakes (Fig. 5) show a strong paleoenvironmental contrast, as the rocks are bright red in color, with indicators for aridity that include pervasive shrinkage cracks, calcrete aridisols, and

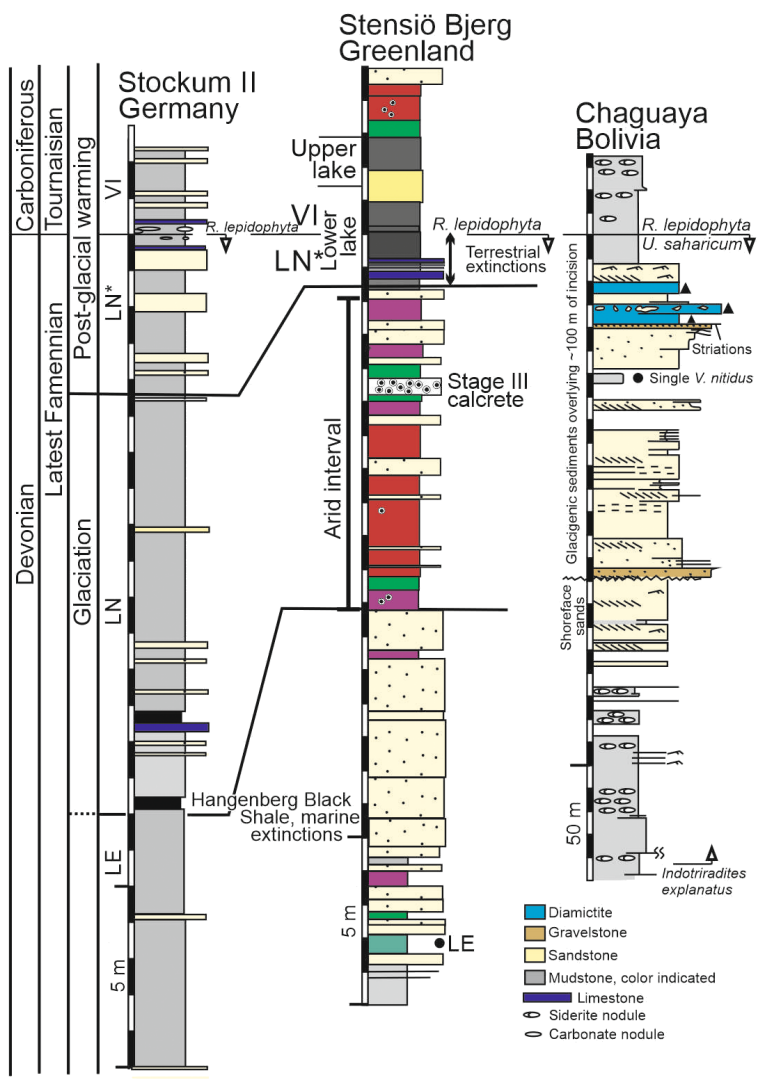

Fig. 5. The D-C boundary correlated between low paleolatitude terrestrial (Stensiö Bjerg, Greenland) and marine shelf [Stockum II, Germany; (11)] sections with high paleolatitude (Chaguaya, Bolivia). The $\mathrm{LN}^{*}$ to VI spore boundary is the correlation tie and the interval of terrestrial extinctions. The terrestrial arid interval on Stensiö Bjerg correlates to the interval at Stockum II between the Hangenberg Black Shale and the $\mathrm{LN}^{*}$ spore zone and equivalent to the glaciation. The Chaguaya composite section (note the reduced scale) includes a channel-filling sandstone of glacigenic origin that terminates immediately below the $\mathrm{D}-\mathrm{C}$ boundary.

a single $50-\mathrm{cm}$-thick stage 3 calcrete that represents an interval of sustained aridity (47). Palynomorphs place this interval as a correlative (10) to the LN spore zone that in marine shelf sections in western Europe (Fig. 5; Stockum II, Germany) includes, at its base, the Hangenberg Black Shale. This widely recognized black shale was at the level at which most of the latest Devonian marine extinctions were concentrated and now reinterpreted (48) as a low paleolatitude response to the forced lowering of sea level during the final glacial cycle of the latest Devonian glaciation. The total time occupied by the latest Devonian glaciation was somewhat longer [ 3 Ma; (49)] and had within it separate orbitally forced glacial to interglacial cycles. Palynological correlations also directly tie this arid interval from east Greenland to sections with glacial diamictites (Fig. 5) both at high paleolatitudes, e.g., Chaguaya, Bolivia $\left(60^{\circ} \mathrm{S}\right)(50,51)$, and in eastern North America (52) (estimated at $30^{\circ} \mathrm{S}$ to $45^{\circ} \mathrm{S}$ ). The multiple occurrences $(52,53)$ of glacial sediment in eastern North America demonstrate the severity of the terminal Devonian glacial cycle that was exceptional for reaching into low paleolatitudes and closer to the equator than any comparable Quaternary glaciation. The evidence from eastern North America includes giant dropstones (53), so the ice centers were not simply at altitude but glaciers were reaching to sea level. Therefore, what we have identified in East Greenland is the 
far-field expression of both the final Devonian glacial cycle as an episode of sustained cool aridity and its subsequent collapse that was an equally severe episode of exceptional warming. This is evidence that the climate system around the D-C boundary had a reduced resilience in that it was more easily perturbed to extremes.

Our discovery provides a model for understanding the extinctions and subsequent recovery of the terrestrial biota at the D-C boundary. The initial phase of extinctions in the marine realm that occurred during deposition of the Hangenberg Black Shale (2) was the response to a glacio-eustatic sea-level fall. These extinctions would have been driven by this pronounced low latitude cooling, its disruptive effects, and the reduction in the area of the shelf seas. The second phase of extinctions, largely occurring in the terrestrial environment, was at a time of warming and caused by loss of the ozone layer. There was a collapse in the terrestrial ecosystem with the global extinction (54) of a number of hitherto very successful and widely distributed plant groups. This habitat destruction and disruption was accompanied by mass extinctions and evolutionary bottlenecks in both fish $(4,55)$ and tetrapods (56) that reset the trajectory of vertebrate evolution. There was also a second phase of extinctions (2) in the trilobites, ammonites, conodonts, chitinozoans, and acritarchs at this time. It is notable that many nektonic marine groups such as the conodonts (57) exhibited a "bloom" of morphotypes within separate lineages and took time to reestablish as stable clades. It can be hypothesized that this was the result of UV-B penetrating (58) into shallow water with a continuing high rate of mutations that would equally have applied to the tetrapods (59) and caused enhanced evolutionary rates during this turning point in their evolution.

The recognition that a known extinction kill mechanism, the loss of the ozone layer, occurred not only during emplacement of a LIP but at times of high global temperature identifies a new mechanism for mass extinctions. Recognition of the significance of bolide impacts (60) and LIPs (3) as kill mechanisms has transformed our understanding of the mass extinction process. However, unlike a LIP or a bolide impact, higher temperatures are a certainty in the immediate future with implications for a similar collapse of the ozone layer.

\section{MATERIALS AND METHODS}

Sedimentary sequences were logged in the field by individual bed-bybed measurements using a tape measure and field notebook. Sampling was done using hammer and chisel. All palynological processing was by standard methods including hydrochloric acid [( $\mathrm{HCl}), 37 \%]$ and then hydrofluoric acid [(HF), 60\%], followed by decant washing to neutral and sieving at $15 \mu \mathrm{m}$. This procedure was followed by a brief short treatment in hot $\mathrm{HCl}$ (37\%) to solubilize neoformed fluorides. The samples were then rapidly diluted into $\sim 200 \mathrm{ml}$ of water and resieved before storing in a vial. No oxidation methods were used in sample preparation. AOM was removed from selected samples by a 15-s treatment with an Ultrasonics and Material ultrasonic probe followed by resieving at $15 \mu \mathrm{m}$. The samples were mounted in Elvacite 2044 with all figured specimens stored in the School of Ocean and Earth Science, University of Southampton. Microscope coordinates (for Olympus BHS-313 210685) and England Finder references are in table S4.

The malformed spores (G. cornuta) were scored on a number of criteria including number of spines, regularity of spine distribution, degree of spine malformation, overall spore shape, and retention in tetrads. These malformations were variably distributed across the group such that it was difficult to produce a single combined score. Hence, to simplify, the spores were counted as either normal, malformed, and/or present within tetrads. Abundant examples of these malformed spores were present, of which a small number are illustrated in Fig. 3 and figs. S7 and S8.

Vitrinite reflectivity $(0.7 \%)$ was measured on coals from the overlying Viséan Traill $\varnothing$ group, 130-m higher in the section. The coals were prepared as blocks and successively polished with 9.5, 3, and $0.05 \mu \mathrm{m}$ of alumina powder on Kemet synthetic laps. Measurements were made using a Zeiss UMSP 50 microspectrophotometer, under oil at $1.516 \mathrm{~nm}$ with a $\times 40$ objective, and calibrated with a YAG (yttrium-aluminum-garnet) standard (0.919\%). Translucency measurements were also made using the UMSP 50 reconfigured for transmitted light at $546 \mathrm{~nm}$ and standardized against $100 \%$ transmittance using the same microscope slide that contained the spores.

The carbon content in the samples for the TOC and calcite profiles was measured using a Carlo Erba EA1108 elemental analyzer. Two to three milligrams of both decarbonated and original sample were separately analyzed with the machine calibrated using a low-C "soil" standard (1.55\%). Every 10 samples, a check was made using the standard as an unknown. The total and acidified carbon analyses were reproportioned to give TOC and mineral carbonate (as calcite) content. Analytical precision is better than $0.2 \%$.

Carbon isotope analysis was undertaken by Iso-Analytical Ltd. using an elemental analyzer linked to a Europa isotope ratio mass spectrometer. Measurements were calibrated to a wheat flour standard $\left(\delta^{13} \mathrm{C}_{\mathrm{V}-\mathrm{PDB}},-26.43 \%\right.$ o $)$ and cross-checked during experimental runs against beet sugar $\left(\delta^{13} \mathrm{C}_{\mathrm{V}-\mathrm{PDB}},-26.03 \%\right.$ ) and cane sugar $\left(\delta^{13} \mathrm{C}_{\mathrm{V}-\mathrm{PDB}}\right.$, $-11.64 \% 0$ ) standards. All are calibrated against the international standard IAEA-CH-6 (sucrose; $\delta^{13} \mathrm{C}_{\mathrm{V}-\mathrm{PDB}},-10.43 \%$ ).

$\mathrm{Hg}$ analyses were by Analytix Ltd. on a Milestone DMA- 80 Tricell mercury analyzer using 20 to $200 \mathrm{mg}$ of powdered rock. The analyzer has a detection limit of $0.003 \mathrm{ng}$ of $\mathrm{Hg}$ and a precision better than $1.0 \%$ with $1 \mathrm{ng}$ of $\mathrm{Hg}$.

\section{SUPPLEMENTARY MATERIALS}

Supplementary material for this article is available at http://advances.sciencemag.org/cgi/ content/full/6/22/eaba0768/DC1

\section{REFERENCES AND NOTES}

1. P. M. Myrow, J. Ramezani, A. E. Hanson, S. A. Bowring, G. Racki, M. Rakociński, High-precision U-Pb age and duration of the latest Devonian (Famennian) Hangenberg event, and its implications. Terra Nova 26, 222-229 (2013).

2. S. I. Kaiser, M. Aretz, R. T. Becker, The global Hangenberg Crisis (Devonian-Carboniferous transition): Review of a first-order mass extinction. Geol. Soc. Lond. Spec. Pub. $\mathbf{4 2 3}$ 387-437 (2016).

3. D. P. G. Bond, S. E. Grasby, On the causes of mass extinction. Palaeogeogr. Palaeoclimatol. Palaeoecol. 478, 3-29 (2017).

4. L. C. Sallan, M. I. Coates, End-Devonian extinction and a bottleneck in the early evolution of modern jawed vertebrates. Proc. Natl. Acad. Sci. U.S.A. 107, 10131-10135 (2010).

5. D. Silvestro, B. Cascales-Miñana, C. D. Bacon, A. Antonelli, Revisiting the origin and diversification of vascular plants through a comprehensive Bayesian analysis of the fossil record. New Phytol. 207, 425-436 (2015).

6. K. Higgs, G. Clayton, J. B. Keegan, Stratigraphic and systematic palynology of the Tournaisian Rocks of Ireland. Geol. Surv. Ireland Spec. Pap. 7, 1-93 (1988).

7. P. M. Van Veen, Aspects of late Devonian and early Carboniferous palynology of Southern Ireland. V. The change in composition of palynological assemblages at the Devonian-Carboniferous boundary. Rev. Palaeobot. Palynol. 34, 67-97 (1981).

8. S. F. Greb, W. A. DiMichele, R. A. Gastaldo, Evolution and importance of wetlands in earth history. Geol. Soc. Am. Spec. Pap. 399, 1-40 (2006).

9. J. P. Benca, I. A. P. Duijnstee, C. V. Looy, UV-B-induced forest sterility: Implications of ozone shield failure in Earth's largest extinction. Sci. Adv. 4, e1700618 (2018). 
10. K. T. Higgs, M. Streel, D. Korn, E. Paproth, Palynological data from the Devonian-Carboniferous boundary beds in the new Stockum Trench II and the Hasselbachtal borehole, Northern Rhenish Massif, Germany. Ann. Soc. Geol. Belg. 115, 551-557 (1993).

11. M. Streel, S. E. Scheckler, Miospore lateral distribution in upper Famennian alluvial lagoonal to tidal facies from eastern United States and Belgium. Rev. Palaeobot. Palynol. 64, 315-324 (1990).

12. F. M. Gradstein, J. G. Ogg, M. Schmitz, G. Ogg, Geological Time Scale (Elsevier, 2020).

13. A.-L. Decombeix, B. Meyer-Berthaud, J. Galtier, Transitional changes in arborescent lignophytes at the Devonian-Carboniferous boundary. J. Geol. Soc. Lond. 168, 547-557 (2011).

14. J. O. Vigran, L. Stemmerik, S. Piasecki, Stratigraphy and depositional evolution of the uppermost Devonian-Carboniferous (Tournaisian- Westphalian) non-marine deposits in North-East Greenland. Palynology 23, 115-152 (1999).

15. K. T. Higgs, C. Prestianni, M. Streel, J. Thorez, High resolution miospore stratigraphy of the Upper Famennian of eastern Belgium, and correlation with the conodont zonation. Geol. Belg. 16, 84-94 (2013).

16. E. Turnau, V. I. Avchimovitch, T. V. Byvscheva, G. Clayton, K. T. Higgs, B. Owens, Taxonomy and stratigraphical distribution of Verrucosisporites nitidus Playford, 1964 and related species. Rev. Palaeobot. Palynol. 81, 289-295 (1994).

17. B. R. Murphy, F. J. G. Mitchell, An association between past levels of ozone column depletion and abnormal pollen morphology in the model angiosperm Arabidopsis thaliana L. Rev. Palaeobot. Palynol. 194, 12-20 (2013).

18. C. B. Foster, S. A. Afonin, Abnormal pollen grains: An outcome of deteriorating atmospheric conditions around the Permian-Triassic boundary. J. Geol. Soc. Lond. 162, 653-659 (2005).

19. R. Hopkins, How ultraviolet light reacts in cells (2015); https://www.nature.com/scitable/ blog/scibytes/how_ultraviolet_light_reacts_in.

20. K. Mičieta, G. Murín, Three species of genus Pinus suitable as bioindicators of polluted environment. Water Air Soil Pollut. 104, 413-422 (1998).

21. H. Visscher, C. V. Looy, M. E. Collinson, H. Brinkhuis, J. H. A. van Konijnenburg-van Cittert, W. M. Kürchner, M. A. Sephton, Environmental mutagenesis during the end-Permian ecological crisis. Proc. Natl. Acad. Sci. U.S.A. 101, 12952-12956 (2004).

22. P. A. Hochuli, E. Schneebell-Hermann, G. Mangerud, H. Bucher, Evidence for atmospheric pollution across the Permian-Triassic transition. Geology 45, 1123-1126 (2017).

23. B. van der Schootbrugge, T. M. Quan, S. Lindström, W. Püttmann, C. Heunisch, J. Pross, J. Fiebig, R. Petschick, H.-G. Röhling, S. Richoz, Y. Rosenthal, P. G. Falkowski, Floral changes across the Triassic/Jurassic boundary linked to flood basalt volcanism. Nat. Geosci. 2, 589-594 (2009).

24. S. Lindström, H. Sanei, B. van de Schootbrugge, G. K. Pedersen, C. E. Lesher, C. Tegner, C. Heunisch, K. Dybkjær, P. M. Outridge, Volcanic mercury and mutagenesis in land plants during the end-Triassic mass extinction. Sci. Adv. 5, eaaw4018 (2019).

25. J. R. Flenley, Why is pollen yellow? And why are there so many species in the tropical rain forest? J. Biogeogr. 38, 809-816 (2011).

26. P. Filipiak, G. Racki, Proliferation of abnormal palynoflora during the end-Devonian biotic crisis. Geol. Quart. 54, 1-14 (2010).

27. C. Prestianni, M. Sautois, J. Denayer, Disrupted continental environments around the Devonian Carboniferous Boundary: Introduction of the tener event. Geol. Belg. 19, 135-145 (2016).

28. L. M. E. Percival, H. C. Jenkyns, T. A. Mather, A. J. Dickson, S. J. Batenburg, M. Ruhl, S. P. Hesselbo, R. Barclay, I. Jarvis, S. A. Robinson, L. Woelders, Does large igneous province volcanism always perturb the mercury cycle? Comparing the records of Oceanic Anoxic Event 2 and the end-Cretaceous to other Mesozoic events. Am. J. Sci. 318, 799-860 (2018).

29. D. P. G. Bond, P. B. Wignall, Large igneous provinces and mass extinctions: An update GSA Spec. Pap. 505, 29-55 (2014)

30. R. E. Ernst, S. A. Rodygin, O. M. Grinev, Age correlation of Large Igneous Provinces with Devonian biotic crises. Global Planet. Change 185, 103097 (2020).

31. O. Paschall, S. K. Carmichael, P. Königshof, J. A. Waters, P. H. Ta, T. Komatsu, A. Dombrowski, The Devonian-Carboniferous boundary in Vietnam: Sustained ocean anoxia with a volcanic trigger for the Hangenberg Crisis? Global Planet. Change 175, 64-81 (2019).

32. H. Sanei, P. M. Outridge, A. Dallimore, P. B. Hamilton, Mercury-organic matter relationships in pre-pollution sediments of thermokarst lakes from the Mackenzie River Delta, Canada: The role of depositional environment. Biogeochemistry 107, 149-164 (2012).

33. J. Kalvoda, T. Kumpan, W. Qie, J. Frýda, O. Bábek, Mercury spikes at the Devonian-Carboniferous boundary in the eastern part of the Rhenohercynian Zone (central Europe) and in the South China Block. Palaeogeogr. Palaeoclimatol. Palaeoecol. 531, 109221 (2019).

34. P. Ward, C. Labandeira, M. Laurin, R. A. Berner, Confirmation of Romer's Gap as a low oxygen interval constraining the timing of initial arthropod and vertebrate terrestrialization. Proc. Natl. Acad. Sci. U.S.A. 103, 16818-16822 (2006).

35. J. A. Clack, C. E. Bennett, D. K. Carpenter, S. J. Davies, N. C. Fraser, T. I. Kearsey, J. E. A. Marshall, D. Millward, B. K. A. Otoo, E. J. Reeves, A. J. Ross, M. Ruta, K. Z. Smithson,
T. R. Smithson, S. A. Walsh, Phylogenetic and environmental context of a Tournaisian tetrapod fauna. Nat. Ecol. Evol. 1, 0002 (2016).

36. S. R. Schachat, C. C. Labandeira, M. R. Saltzman, B. D. Cramer, J. L. Payne, C. K. Boyce, Phanerozoic $\mathrm{pO}_{2}$ and the early evolution of terrestrial animals. Proc. R. Soc. B 285 20172631 (2018).

37. C. M. Belcher, J. M. Yearsley, R. M. Hadden, J. C. McElwain, G. Rein, Baseline intrinsic flammability of Earth's ecosystems estimated from paleoatmospheric oxygen over the past 350 million years. Proc. Natl. Acad. Sci. U.S.A. 107, 22448-22453 (2010).

38. H. Olsen, Sedimentary basin analysis of the continental Devonian basin in North-East Greenland. Bull. Grønlands Geol. Unders. 168, 1-80 (1993).

39. T. H. Torsvik, L. R. M. Cocks, Earth History and Palaeogeography (Cambridge Univ. Press, 2017).

40. W. Ehrmann, G. Schmeidel, S. Beuscher, S. Krüger, Intensity of African humid periods estimated from Saharan dust fluxes. PLOS ONE 12, e0170989 (2017).

41. T. Vollmer, R. Wemer, M. Weber, N. Tougiannidis, H.-G. Röhling, U. Hambach, Orbital control on Upper Triassic playa cycles of the Steinmergel-Keuper (Norian): A new concept for ancient playa cycles. Palaeogeogr. Palaeoclimatol. Palaeoecol. 267, 1-16 (2008).

42. H. Olsen, Orbital forcing on continental depositional systems-Lacustrine and fluvial cyclicity in the Devonian of East Greenland. Spec. Publs Int. Ass. Sediment. 19, 429-438 (1994).

43. J. G. Anderson, D. M. Wilmouth, J. B. Smith, D. S. Sayres, UV dosage levels in summer: Increased risk of ozone loss from convectively injected water vapour. Science 337, 835-839 (2012).

44. M. L. Caplan, R. M. Bustin, Devonian-Carboniferous Hangenberg mass extinction event, widespread organic-rich mudrock and anoxia: Causes and consequences. Palaeogeogr. Palaeoclimatol. Palaeoecol. 148, 187-207 (1999).

45. M. G. Scarratt, R. M. Moore, Production of methyl bromide and methyl chloride in laboratory cultures of marine phytoplankton II. Mar. Chem. 59, 311-320 (1998)

46. T. R. Astin, J. E. A. Marshall, H. Blom, C. M. Berry, The sedimentary environment of the Late Devonian East Greenland tetrapods. Geol. Soc. Lond. Spec. Pub. 339, 93-109 (2010).

47. G. J. Retallack, A Colour Guide to Paleosols (Wiley, 1997).

48. O. J. Bábek, T. Kumpan, J. Kalvoda, T. M. Grygar, Devonian/Carboniferous boundary glacioeustatic fluctuations in a platform-to-basin direction: A geochemical approach of sequence stratigraphy in pelagic settings. Sed. Geol. 337, 81-99 (2016).

49. R. Wicander, G. Clayton, J. E. A. Marshall, I. Troth, A. Racey, Was the latest Devonian glaciation a multiple event? New palynological evidence from Bolivia. Palaeogeogr. Palaeoclimatol. Palaeoecol. 305, 75-83 (2011).

50. P. E. Isaacson, E. Díaz-Martinez, G. W. Grader, J. Kalvoda, O. Babek, F. X. Devuyst, Late Devonian-earliest Mississippian glaciation in Gondwanaland and its biogeographic consequences. Palaeogeogr. Palaeoclimatol. Palaeoecol. 268, 126-142 (2008).

51. J. A. Lakin, J. E. A. Marshall, I. Troth, I. C. Harding, Greenhouse to icehouse: A biostratigraphic review of latest Devonian-Mississippian glaciations and their global effects. Geol. Soc. Lond. Spec. Pub. 423, 439-464 (2016).

52. D. K. Brezinski, C. B. Cecil, V. W. Skema, Late Devonian glacigenic and associated facies from the central Appalachian Basin, eastern United States. GSA Bull. 122, 265-281 (2010).

53. F. R. Ettensohn, J. C. Pashin, W. Gilliam, The Appalachian and Black Warrior Basins: Foreland basins in the eastern United States, in The Sedimentary Basins of the United States and Canada, A. D. Miall, Ed. (Elsevier, ed. 2, 2019), pp. 129-237.

54. D. Edwards, M. Fairon-Demaret, C. M. Berry, Plant megafossils in Devonian stratigraphy: A progress report. Cour. Forsch.-Inst. Senckenberg 220, 25-37 (2000).

55. M. Friedman, L. C. Sallan, Five hundred million years of extinction and recovery: A Phanerozoic survey of large-scale diversity patterns in fishes. Palaeontology $\mathbf{5 5}$ 707-742 (2012).

56. T. R. Smithson, S. P. Wood, J. E. A. Marshall, J. A. Clack, Earliest Carboniferous tetrapod and arthropod faunas from Scotland populate Romer's Gap. Proc. Natl. Acad. Sci. U.S.A. 109, 4532-4537 (2012).

57. S. I. Kaiser, T. Kumpan, M. W. Rasser, High-resolution conodont biostratigraphy in two key sections from the Carnic Alps (Grüne Schneid) and Graz Paleozoic (Trolp)_Implications for the biozonation concept at the Devonian-Carboniferous boundary. Newsl. Stratigr. (2020).

58. E. M. Fleischmann, The measurement and penetration of ultraviolet radiation into tropical marine water. Limnol. Oceanogr. 34, 1623-1629 (1989).

59. S. M. Starnes, C. A. Kennedy, J. W. Petranka, Sensitivity of embryos of southern Appalachian amphibians to ambient solar UV-B radiation. Conserv. Biol. 14, 277-282 (2000).

60. L. W. Alvarez, W. Alvarez, F. Asaro, H. V. Michel, Extraterrestrial cause for the Cretaceous-Tertiary extinction. Science 208, 1095-1108 (1980).

61. H. Olsen, P.-H. Larsen, Lithostratigraphy of the continental Devonian sediments in North-East Greenland. Geol. Surv. Den. Greenl. 165, 1-108 (1993).

62. N. Henriksen, Geological History Of Greenland (GEUS, Denmark, 2008).

63. P.-H. Larsen, H. Olsen, J. A. Clack, The Devonian basin in East Greenland-Review of basin evolution and vertebrate assemblages. GSA Memoir 202, 273-292 (2008). 
64. H. Blom, J. A. Clack, P. E. Ahlberg, M. Friedman, Devonian vertebrates from East Greenland: A review of faunal composition and distribution. Geodiversitas 29, 119-141 (2007).

65. H. Blom, J. A. Clack, P. E. Ahlberg, Localities, distribution and stratigraphical context of the Late Devonian tetrapods of East Greenland. Medd. Grønl. Geosci. 43, 1-50 (2005).

66. J. E. A. Marshall, T. R. Astin, J. A. Clack, The East Greenland tetrapods are Devonian in age. Geology 27, 637-640 (1999).

67. M. Streel, J. E. A. Marshall, Devonian-Carboniferous boundary global correlations and their paleogeographic implications for assembly of Pangaea. Proc. XVth Int. Cong. Carb. Perm. Strat. 2006, 481-496 (2006).

68. N. Maziane, K. T. Higgs, M. Streel, Biometry and paleoenvironment of Retispora lepidophyta (Kedo)Playford 1976 and associated miospores in the latest Famennian nearshore marine facies, eastern Ardenne (Belgium). Rev. Palaeobot. Palynol. 118, 211-226 (2002).

69. M. Streel, K. Higgs, S. Loboziak, W. Riegel, P. Steemans, Spore stratigraphy and correlation with faunas and floras in the type marine Devonian of the Ardenne-Rhenish regions. Rev. Palaeobot. Palynol. 50, 211-229 (1987).

70. J. E. A. Marshall, B. J. Stephenson, Sedimentological responses to basin initiation in the Devonian of East Greenland. Sedimentology 44, 407-419 (1997).

71. M. Friedman, H. Blom, A new actinopterygian fish from the Famennian of East Greenland and the interrelationships of Devonian ray-finned fishes. J. Paleont. 80, 1186-1204 (2006)

72. J. E. A. Marshall, K. W. Glennie, T. R. Astin, A. J. Hewett, The Old Red Group (Devonian) - Rotliegend (Permian) Unconformity in the Inner Moray Firth. Geol. Soc. Lond. Spec. Pub. 471, 237-252 (2019).

73. J. Shen, J. Chen, T. J. Algeo, S. Yuan, Q. Feng, J. Yu, L. Zhou, B. O'Connell, N. J. Planavsky, Evidence for a prolonged Permian-Triassic extinction interval from global marine mercury records. Nat. Commun. 10, 1563 (2019).

74. H. S. Morgans-Bell, A. L. Coe, S. P. Hesselbo, H. C. Jenkyns, G. P. Weedon, J. E. A. Marshall, R. V. Tyson, C. J. Williams, Integrated stratigraphy of the Kimmeridge Clay Formation (Upper Jurassic) based on exposures and boreholes in south Dorset, UK. Geol. Mag. 138 511-539 (2001).

75. C. E. Barker, M. J. Pawlewicz, Calculation of vitrinite reflectance from thermal histories and peak temperatures: A comparison of methods. ACS Symp. Ser. Am. Chem. Soc. $\mathbf{5 7 0}$ 216-229 (1994).
76. A. C. Scott, I. J. Glasspool, Observations and experiments on the origin and formation on the inertinite group macerals. Int. J. Coal Geol. 70, 53-66 (2007).

77. S. Hillier, J. E. A. Marshall, A rapid technique to make polished thin sections of sedimentary organic matter concentrates. J. Sediment. Res. 58, 754-755 (1988).

Acknowledgments: Support from CASP (Cambridge Arctic Shelf Programme) has been essential for the East Greenland fieldwork and particularly assistance from the late A. Whitham and C. Johnson (Polar Sphere). Crucial early fieldwork was with T. Astin (1996). F. Nexøe-Larsen, R. Painting, E. Fleming, S. Johnson, C. Berry, H. Blom, and V. Dupret variously accompanied us to the summits of Stensiö Bjerg, Celsius Bjerg, and Rebild Bakker. Critical reading was by J. Clack, A. Whitham, and P. Wilson. S. Akbari (Southampton) prepared the palynological samples and operated the elemental analyzer. J. Smith from Analytix and P. Gaca (Southampton) provided the mercury analyses. The Natural Environment Research Council TW:eed Project provided impetus to keep thinking about the D-C boundary extinctions. Colleagues in the NERC UV-B consortium (NE/N001795/1) and particularly B. Lomax provided much positive discussion. Funding: National Geographic (GEFNE52-12) supported, in part, the 2012 field season (Fig. 2); otherwise, there was no specific grant funding for this project. J.L.'s Ph.D. thesis was funded, in part, by the Engineering and Physical Science Research Council. Author contributions: J.E.A.M. designed the project and conducted the majority of the research. J.L. carried out the research in Bolivia, supervised by J.E.A.M. and I.T. All contributed to fieldwork and section logging in East Greenland, with J.L. and S.M.W.-J. contributing to data collection for Fig. 2. Competing interests: The authors declare that they have no competing interests. Data and materials availability: All data needed to evaluate the conclusions in the paper are present in the paper and/or the Supplementary Materials. Additional data related to this paper may be requested from the authors.

Submitted 2 November 2019

Accepted 23 March 2020

Published 27 May 2020

$10.1126 /$ sciadv $a b a 0768$

Citation: J. E. A. Marshall, J. Lakin, I. Troth, S. M. Wallace-Johnson, UV-B radiation was the Devonian-Carboniferous boundary terrestrial extinction kill mechanism. Sci. Adv. 6, eaba0768 (2020). 


\section{ScienceAdvances}

\section{UV-B radiation was the Devonian-Carboniferous boundary terrestrial extinction kill mechanism}

John E. A. Marshall, Jon Lakin, Ian Troth and Sarah M. Wallace-Johnson

Sci Adv 6 (22), eaba0768.

DOI: $10.1126 /$ sciadv.aba0768

ARTICLE TOOLS

SUPPLEMENTARY

MATERIALS

REFERENCES

PERMISSIONS http://advances.sciencemag.org/content/6/22/eaba0768

http://advances.sciencemag.org/content/suppl/2020/05/21/6.22.eaba0768.DC1

This article cites 70 articles, 16 of which you can access for free http://advances.sciencemag.org/content/6/22/eaba0768\#BIBL

http://www.sciencemag.org/help/reprints-and-permissions

Science Advances (ISSN 2375-2548) is published by the American Association for the Advancement of Science, 1200 New York Avenue NW, Washington, DC 20005. The title Science Advances is a registered trademark of AAAS.

Copyright @ 2020 The Authors, some rights reserved; exclusive licensee American Association for the Advancement of Science. No claim to original U.S. Government Works. Distributed under a Creative Commons Attribution NonCommercial License 4.0 (CC BY-NC). 